\title{
THE EVOLUTION OF HOSPITALS FROM ANTIQUITY TO THE RENAISSANCE
}

\begin{abstract}
There is some evidence that a kind of hospital already existed towards the end of the $2^{\text {nd }}$ millennium BC in ancient Mesopotamia. In India the monastic system created by the Buddhist religion led to institutionalised health care facilities as early as the $5^{\text {th }}$ century BC, and with the spread of Buddhism to the east, nursing facilities, the nature and function of which are not known to us, also appeared in Sri Lanka, China and South East Asia. One would expect to find the origin of the hospital in the modern sense of the word in Greece, the birthplace of rational medicine in the $4^{\text {th }}$ century BC, but the Hippocratic doctors paid house-calls, and the temples of Asclepius were visited for incubation sleep and magico-religious treatment. In Roman times the military and slave hospitals were built for a specialised group and not for the public, and were therefore not precursors of the modern hospital. It is to the Christians that one must turn for the origin of the modern hospital. Hospices, originally called xenodochia, initially built to shelter pilgrims and messengers between various bishops, were under Christian control developed into hospitals in the modern sense of the word. In Rome itself, the first hospital was built in the $4^{\text {th }}$ century AD by a wealthy penitent widow, Fabiola. In the early Middle Ages ( $6^{\text {th }}$ to $10^{\text {th }}$ century), under the influence of the Benedictine Order, an infirmary became an established part of every monastery. During the late Middle Ages (beyond the $10^{\text {th }}$ century) monastic infirmaries continued to expand, but public hospitals were also opened, financed by city authorities, the church and private sources. Specialised institutions like leper houses also originated at this time. During the Golden Age of Islam the Muslim world was clearly more advanced than its Christian counterpart with regard to the magnificent hospitals which were built in various countries, institutions which eventually became the true forerunners of the modern teaching hospital.
\end{abstract}

\section{INTRODUCTION}

Public health was until relatively recently very low on the list of priorities in the Western world - in fact, it only became a national objective in some countries in the late $18^{\text {th }}$ century. This is, however, not surprising when one considers all the forces working against it since the beginning of Western civilisation, especially in Greece and Rome. Various factors prevented the early development of an adequate health service, for instance ignorance, the unsympathetic attitude of the Greeks and Romans towards the sick, superstition and religious beliefs. There were, however, also positive measures taken by the Roman government in par- 
ticular to promote public health, like the appointment of state physicians and free medical services to the poor. The provision of a relatively advanced infrastructure in the form of aqueducts to provide sufficient fresh water for the population, a network of gigantic sewers underneath the city for the disposal of sewage, and numerous public baths all over the city were further ways of promoting hygiene.

From a modern point of view, the most important and lasting contribution of the ancients to public health was the establishment of the hospital in the modern sense of the word, i.e. an institution where the sick and disabled could receive treatment for a period of time. It is, strangely, not in Greece, the birthplace of rational medicine in the $4^{\text {th }}$ century $\mathrm{BC}$ that one finds the origin of the hospital, nor in the temples of Asclepius, or even the Roman military and slave hospitals which can be traced back to the $1^{\text {st }}$ century $\mathrm{BC}$. It is to the Christians that we owe the origin of the modern hospital — perhaps paradoxically, because in certain respects Christianity had a rather negative effect on medicine: anatomy was denounced, human dissection was prohibited because a man's body is the temple of the Holy Spirit, the occurrence of miracles advanced superstition, and diseases were regarded as a punishment for sin. However, Christian contribution lay on another plain, namely compassion with and caring for the sick. Under their control hospices built to shelter pilgrims and messengers between bishops developed into hospitals in the modern sense of the word.

Sir William Osler once said that Imhotep, grand vizier to king Zoser (Third Dynasty, c. 3000 BC, and builder of the first pyramid at Sakkara), was "the first figure of a physician to stand out clearly from the mists of antiquity" (Major 1954:39-40). If we assume that our written records of medical endeavour do date back to that distant era of Egyptian and Mesopotamian development, it is indeed surprising that hospitals as we know them today did not appear until the $4^{\text {th }}$ century AD. However, evidence that forerunners of hospitals might have existed in the $2^{\text {nd }}$ millenium $\mathrm{BC}$ will be discussed. In this article the development of the hospital is traced from its onset up to the end of the Middle Ages, with emphasis on Europe and the Near East. 


\section{DEFINITION OF TERMS}

A bospital is defined as a room, rooms or building specifically employed for the investigation and continued treatment of the diseased. For the purpose of this study, the Greek iatreion and Roman taberna medica, comparable to the modern physician's consulting room, are excluded from consideration (Harig 1971:184-185), but it is accepted that under special circumstances these rooms might well have been put to shortterm use as hospital equivalents (Woodhead 1952:245).

The words hospital, hottel, spital and hospice are all derived from the Latin word bospitium meaning "a place of entertainment for strangers, a lodging, an inn, a guest-chamber" (Lewis \& Short 1958:867). In late Christian times such bospitia were often attached to a monastery and primarily intended for accommodating pilgrims. Today a hospice usually indicates a home for the terminally ill. The word bôtel is an early French term, and is a forerunner of the present word which refers to a building offering accommodation to paying guests - with no connection to illness (Aitken 1984:9-11).

The word infirmary (from Latin infirmarium) originally referred to a room or rooms attached to a monastery for the treatment of diseased monks (Aitken 1984:9-11). In the Roman world a valetudinarium referred to a hospital initially solely for the treatment of military personnel, but the word was later also used to denote hospitals for the civic population (Scheider 1953:262-264). In the monastic period the term nosocomium came into use to indicate a small Roman type hospital, while the Greek word xenodochion which initially denoted a home for strangers and the poor, eventually referred to charitable hospitals in the early Christian era (Allen 1990:447-450).

During the Golden Age of Islam ( $9^{\text {th }}-13^{\text {th }}$ centuries) the Persian word bimaristan denoted a hospital, while maristan referred to an institution for the insane (Major 1954:229; Porter 1997:105).

\section{EARLIEST TIMES}

There is some evidence that the earliest hospitals known to us may have been in ancient Mesopotamia. Reiner (1964:544-549) presents evidence that royal physicians at Assyrian and Babylonian courts to- 
wards the end of the $2^{\text {nd }}$ millennium BC, cared for ill court singers in what were probably elementary hospitals or nursing homes. Classical sources also refer to possible hospitals in the Hellenistic Age attached to the Egyptian temples for Saturn in places like Heliopolis, Memphis and Thebes. However, this probably denoted sleeping accommodation in temple precincts, rather like that associated with the Asclepian cult (Aitken 1984:7).

The Buddhist religion with its roots in $6^{\text {th }}$ century BC India led to the creation of a monastic system, which, as with subsequent Christianity, gave rise to institutionalised health care facilities in and around these monasteries as early as the $5^{\text {th }}$ century BC. The nursing profession may also have originated here $\left(5^{\text {th }}\right.$ century $\left.\mathrm{BC}\right)$, and we are told that Sri Lankan hospitals date back to $431 \mathrm{BC}$. We know very little about the nature and function of these institutions, but the great Indian king, Asoka, is credited with the construction of hospitals for humans and also for animals during the $3^{\text {rd }}$ century BC (Aitken 1984:7; Haeger 1988:53-54). With the eastward spread of Buddhism, so-called hospitals, almshouses and convalescent homes also appeared in China (perhaps as early as the $5^{\text {th }}$ century BC) and South East Asia. The precise nature of these institutions is obscure (Major 1984:100; Philips 1993:149; Chrystal 2000:536).

In antiquity the Mosaic laws covered health matters extensively, but the Jewish nation is not associated with the founding of hospital systems (Major 1954:55-65). The Bible does not mention such institutions, but we do know of persons treated for illness in private homes, e.g. the child in Zarephath (I Kings 17:17-24), Lazarus (John 11:6-25), the centurion's child (Luke 7:1-9), the illness of king Ahaziah (2 Kings 1:1-16) and the Good Samaritan in the parable (Luke 10:34, 35).

\section{GRAECO-ROMAN ERA}

Primitive health care associated with the temples of Asclepius are considered by many to have been the forerunners of true hospitals (Thompson 1975:3, 4). Founded at Epidaurus in the $5^{\text {th }}$ century BC (Fig. 32), the Asclepian cult revolved around temple complexes usually built at scenic, wooded sites with an abundant water supply. Asclepiea were later built all over the Roman Empire, and flourished up to $391 \mathrm{AD}$ when as 


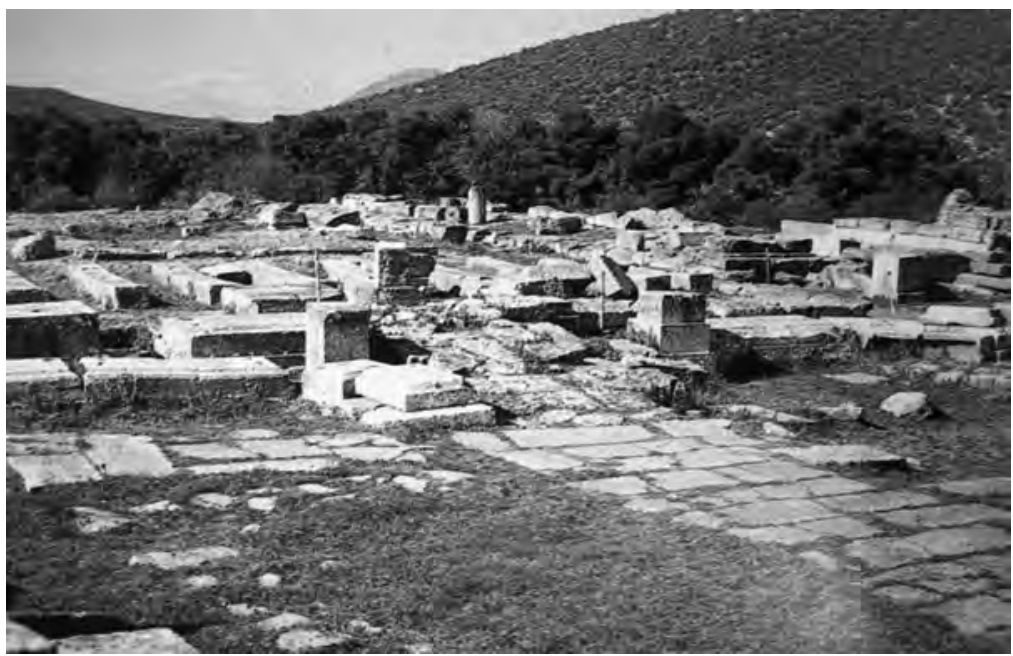

Figure 32: Remains of the sanctuary of Asclepius, Epidaurus.

pagan temples, they were officially closed by the Christian emperor Theodosius I. Their structure was fairly standardised, usually consisting of large rooms, closed on three sides, orientated to the sun and opening to the south with a row of pillars in the form of a Greek stoa (portico). Big Asclepiea like that at Pergamum included treatment halls, libraries, a stadium, baths and latrines.

Patients normally entered the temple for incubation sleep in the stoa (Fig. 33). Their dreams were then interpreted by priests, who also suggested the appropriate therapy (Thompson 1975:3-4). The hypochondriacal Aelius Aristides for instance, relates how he spent considerable time as a patient in the home of an Asclepian temple warden, and how in consultation with a physician he was given a therapeutic medicament after his dreams had been interpreted (Orations 48.34-35, 46-49). Therapy was mainly of magico-mystic nature, and completely alien to the co-existing Hippocratic medicine which was based on contemporary scientific knowledge and abhorred the occult in medicine. There was, however, ironically, a famous Asclepieum on the island of Cos, where Hippocrates taught. The Hippocratic doctors visited and treated patients at their homes and performed the occasional surgical 


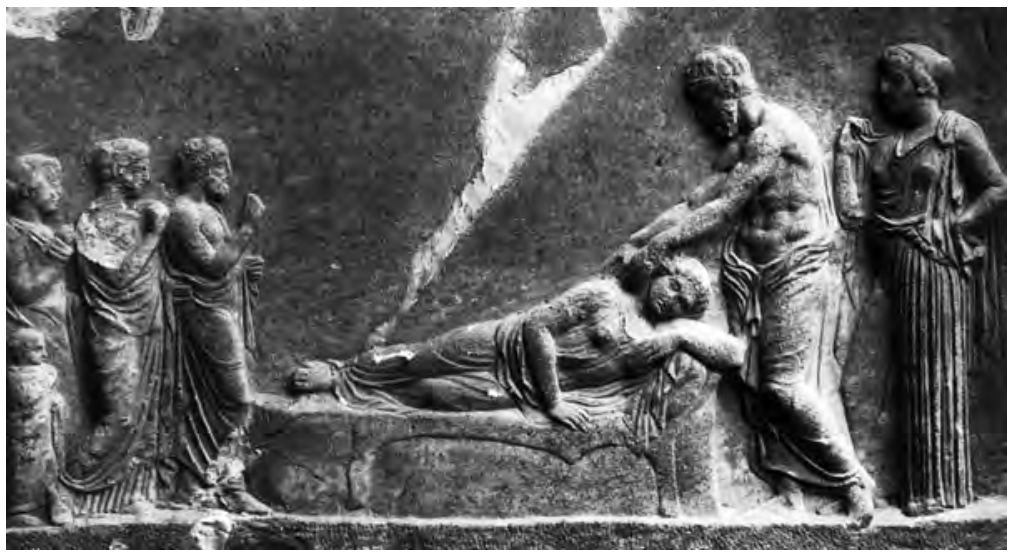

Figure 33: Incubation sleep: Asclepius, attended by Hygiea, treats a sleeping woman. Votive relief, $4^{\text {th }}$ century BC. Piraeus Museum.

procedure, but there is no evidence in Classical Greece of the use of hospitals in the modern sense of the word, although there is suggestive evidence that rooms in private homes were occasionally adapted for longer term medical treatment (Major 1954:121-136; Woodhead 1952:245; Harig 1971:183).

The first official step taken by the Roman government in public health care - other than the passing of various laws in this regard (Cilliers 1993) — was the establishment in 293 BC of a temple of Aesculapius on the Tiber island in the aftermath of a disastrous epidemic. In the crisis the Senate took the traditional step and consulted the prophetic Sibylline books; the recommendation was to import the cult of Asclepius, the Greek god of medicine, from its main centre at Epidaurus. Tradition has it (Ovid, Metamorphoses 15.669ff.; Livy 10.47 and Valerius Maximus 1.8.2) that a serpent (the symbol of the god) came on board the ship at Epidaurus of its own accord, and when the mission arrived at Rome, it swam ashore to an islet in the Tiber. After the epidemic had subsided, the Romans in gratitude for their deliverance built a temple to the god on the island. What probably happened in reality was that the Roman state, due to the unsophisticated stage in which health care was in the $3^{\text {rd }}$ century $\mathrm{BC}$, sought outside assistance. 
The advice from the priests in Epidaurus was that it would be more hygienic to treat the sick outside the built-up area of the city. Therefore the temple of Aesculapius was built on an island in the Tiber, outside the precincts of Rome. This Asclepieum (Fig. 34) later became known as the "Slave hospital" because of the accumulation of slaves, taken there when chronically ill (to avoid expenses for the owners) and never re-collected by their masters. ${ }^{1}$ In Christian times the hospital became famous as the St. Bartholomew Hospital and provided shelter for sick pilgrims - a function which it has in effect retained since. On the site once occupied by the ancient temple there now stands a modern hospital run by a religious order (Staccioli 1989:60).

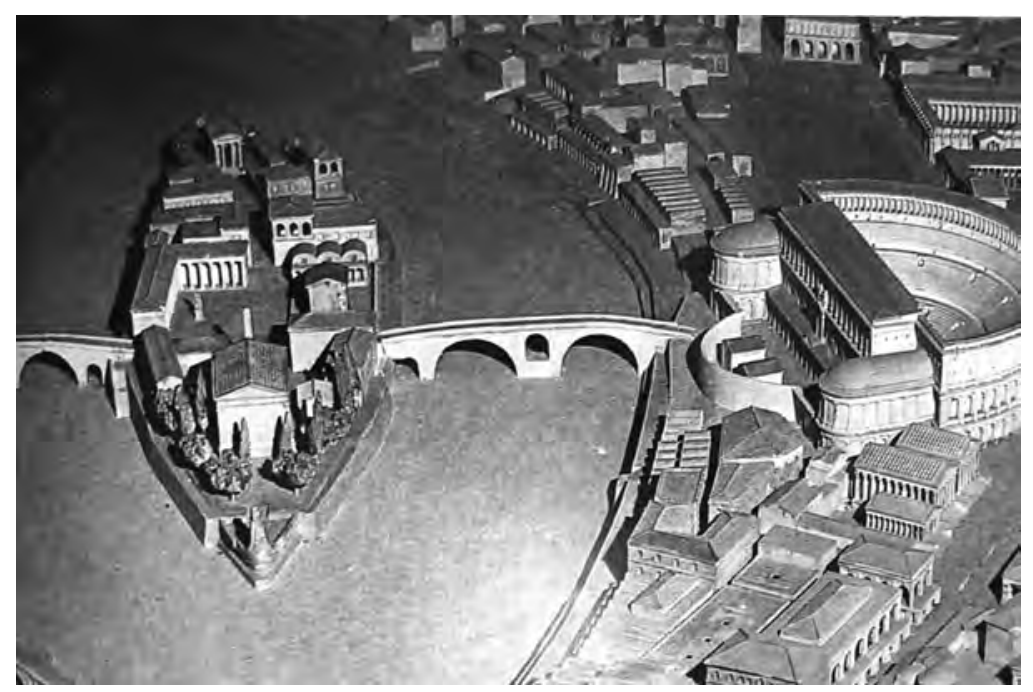

Figure 34: Reconstruction of the Asclepieum on the Tiber island.

With the probable exception of valetudinaria (described below), ancient Rome, like Greece, had no public institutions where sick civilians could be treated for a longer period of time (Majno 1975:393).

1 According to Suetonius, Divus Claudius c. 25 and Digesta 40.8.2, such slaves were freed by an edict of the emperor Claudius. 
The poorer patients were brought to the doctor's iatreion/taberna where they were treated and then sent home, while the rich were visited at home by the doctor. This custom of treating the sick at home (cf. Celsus I.65; Cato I.1 and 2; Columella XI.1.18; XII.1.60) still obtained in the time of the Roman Empire, as is evident from an event described by Tacitus (Annales IV.63). During a disaster which took place in a small town near Rome when an amphitheatre collapsed, the injured were taken to private houses where they were treated by physicians. If a hospital had existed, the injured would have been there, not in private houses. Even as late as the $3^{\text {rd }}$ century AD there is still no evidence of hospitals, as is clear from a remark made by Aelius Lampridius (Scriptores Historiae Augustae Alex. Sev. c.47) that the emperor Alexander Severus (AD 222-235) distributed those who were seriously ill between the individual families to be cared for.

With the extension of the Roman Empire, when it was no longer possible to send wounded and sick soldiers home for treatment, military hospitals were established. Two kinds of hospitalisation existed: permanent fort hospitals erected at strategic points (valetudinaria) (Fig. 11), and temporary field hospitals at the front during active campaigns (Scheider 1953:262-264; Thompson 1975:4-6; Jackson 1988:133-137).

The first valetudinarium was probably built in the $1^{\text {st }}$ century BC at Carnuntum (near Vienna). These soldiers' hospitals became part of established Roman fort architecture and were usually placed near the outer wall in a quiet part of the fortification. Valetudinaria were placed in major as well as in smaller forts for auxiliary troops — the size varying with the size of the fort. The larger hospitals traditionally consisted of four wings with a central open courtyard. The number of wards roughly matched the number of centuries in the legion, each accommodating no more than three beds, and designed for maximal privacy. Usually there were treatment rooms, a dispensary, staff quarters, and washing, cooking and latrine facilities. Calculations suggest that about $5 \%$ of the unit's strength could be accommodated, although this number could easily be doubled by utilising corridors and ancillary rooms.

Each military unit had its doctors (milites medici) and medical assistants (capsarii — named after the bandage box, capsa). Behind the lines the field hospital (housed in tents) was the medical responsibility of the 
camp prefect, second-in-command and most experienced soldier of the unit. It was actually administered by the optio valetudinarii, a junior HQ officer who was an administrator rather than a doctor. Adequate supply lines to these field hospitals had high priority; in times of starvation the army was the last to suffer. The number and experience of medical staff varied according to the size and prestige of the unit, and staff were probably organised into an overall hierarchy of military doctors serving the valetudinaria. There was also a specialised person (the marsus) who looked after snake bites and other problems of envenomisation (the Marsi were a mountain tribe famous for miraculous snake-bite cures, Hornblower 1996:930).

Although Jackson (1988:65) points out that we have no archaeological proof of civilian hospitals, there is evidence that hospitals, also called valetudinaria, were later also established for the civilian population and upper classes in particular, for imperial staff in provincial cities (probably private institutions), and for gladiators and slaves on large farms (latifundia) (Harig 1971:189, 193-195; Thompson \& Golden 1975:4). Landowners realised the necessity of keeping their labour force healthy in order to ensure that they could fulfil their duties. ${ }^{2}$ There is little information on how these institutions were run, but they were probably a combination of private and state-run establishments. Although Woodhead (1952:245) suggests that doctors' tabernae often evolved into sanatoria and small house-hospitals (nosocomia), this is little more than speculation. Harig (1971:183-187) warns that evidence for pronouncing even the well-known "physician's home" in Pompeii a househospital, is slim. However, he speculates that serious accident cases might well have received prolonged therapy in a doctor's house. We therefore must accept that the valetudinaria played no direct role in the evolution of the public hospital - they were established for a particular purpose and for a particular class of patient. Not even the term valetudinarium survived - when hospitals for the general public did arise, they initially became known by the Greek term xenodochia (Allan 1990:446-447). Well-to-do households did however have their own treatment quarters for the ill (Seneca, De Ira 1.16.4). It is interesting to note that the famous Roman architect, Vitruvius, insisted that careful

2 In a treatise on agriculture Columella (Rust. XI.1.18), a contemporary of St. Paul, specifically pointed out the need for providing such valetudinaria for slaves. 
The evolution of hospitals

analysis of the environment's health status be performed before establishing new cities and presumably hospitals (De arch. I.4).

\section{THE CHRISTIAN ERA}

Even during the early phase of the Christian era when Christians suffered severe religious persecution, their selfless dedication to relief of the suffering of the poor and ill, was remarked on by historians (Cyprian, De mortalitate VI.1-2; Eusebius, Hist. Eccl. IX.7.15-8.3). The Christians' typical attitude towards the sick was based on Christ's parable of the Good Samaritan - mercy and compassion for anyone in need. This ethos of caring did however not translate into action regarding hospitalisation until Emperor Constantine promulgated his Edicts of Toleration in 311 and 313 granting religious freedom. And then their charitable actions, concentrating on the needs of the wretched, did not differentiate between assistance for paupers, pilgrims, orphans, the aged, insane and the diseased (Thompson \& Golden 1975:6; Ferngren \& Amundsen 1996:2971-2975). The earliest hospices for instance, called xenodochia in the mainly Greekspeaking East, initially built to shelter pilgrims and messengers between the various bishops, eventually also housed disadvantaged, diseased and mentally infirm persons. In the course of time, many of these developed into standard hospitals (Allan 1990:447). By the $4^{\text {th }}$ century xenodochia were well-known institutions in the West as well, mainly because the emperor Julian the Apostate (361-363), in his attempt to revive paganism, tried to attract support by establishing xenodochia such as the Christians had. In a letter to Arsacius, his pagan high priest in Galatia, Julian wrote: "In every city establish xenodochia in order that strangers may profit by our benevolence" (Epistula 49). About a century later (470) we also find the law of the emperors Leo and Anthemius ordering the establishment of xenodochia (Codex Justiniani I.i. tit.3).

With the rapid rise of Christian monasticism, it was logical that charitable endeavours would often emanate from monasteries. Infirmaries originated as health care facilities inside monasteries, designed for care of the monks. In time infirmaries also took in civilian patients, and even later treatment originally supplied by the monks themselves, was supplemented by help from physicians from outside the institution. In this way monasteries played a vital role in promoting health care and developing hospitals. These hospitals were now supported by 
Christian charity, and were no longer founded on the state's economic considerations, as had largely been the case in earlier Roman times (Thompson \& Golden 1975:6).

St. Basil of Caesarea (in Cappadocia) was a pioneer in establishing hospitalisation and care of the disabled and sick. In 369 he founded the celebrated Basilica at Caesarea, comprising a hospital which apparently had as many wards as there were diseases, and even included a section for lepers who had previously been kept in isolation and were now for the first time really cared for. The hospital also had extended quarters for medical staff, workshops, hospices for travellers and the poor, as well as an industrial school. We happen to have a detailed description of this hospital in an oration of Gregory of Nazianus, who delivered St. Basil's funeral oration (Orations xliii). At St. Basil's insistence, hospitals were also built in neighbouring regions, and the Eastern Roman Empire often gave state assistance. At Edessa, for instance, a 300 bedded hospital was established by St. Ephraim in the aftermath of an epidemic in 375. In the following century a series of monasterybased hospitals, often with associated buildings for orphans and the poor, sprang up in many cities. In Rome the first hospital was founded in 390 by a Roman lady, Fabiola, a wealthy widow who sought absolution by spending her wealth on charitable works (recorded by Jerome, Epistula lxxvii, Ad Oceanum de morte Fabiolae). Two other wealthy ladies, Pulcheria and Pauline, later followed her example and built or endowed hospitals in respectively Constantinople and Jerusalem. The Empress Eudoxia (401-465) also ordered the building of a hospital in Jerusalem (Aitken 1984:9-11; Allan 1990:452-454).

The fall of Rome in 476 precipitated a prolonged period of developmental stagnation in Europe (the so-called Dark Ages), but chiefly because of Christian monastic influences hospitalisation still moved forward.

\section{MEDIEVAL TIMES}

\subsection{Early Middle Ages ( $6^{\text {th }}$ to $10^{\text {th }}$ centuries)}

By the middle of the $6^{\text {th }}$ century the establishment of hospitals was securely anchored in the Eastern as well as the Western parts of the Roman 
Empire, due also to the support of various monarchs. Childebert, King of the Franks, founded the Hôtel Dieu in Lyons in 542, and Theodoric the Great (493-526) encouraged any Christian initiative concerned with hospitalisation. Charlemagne (747-814) promulgated a decree that a school, monastery and hospital be attached to every cathedral built in his territory (Aitken 1984:10, 11; Haeger 1988:55, 70-71). The term xenodochion now began to give place to hospitalium — in a letter written in AD 796, the English scholar and ecclesiastic, Alcuin, urged Eanbald II, Archbishop of York, to found in his diocese "xenodochia, id est hospitalia" (Wallach 1951: Letter 56, Ad Eanbaldum).

With the founding of a monastery and hospital at Montecassino in Italy in 529, St. Benedict of Nursia launched one of the most influential of all Medieval initiatives in the field of hospitalisation. $\mathrm{He}$ insisted on excellence and dedication in the care of illness, and in time his Benedictine Order became the model for later monastic establishments. ${ }^{3}$ In 742 a Church Council decreed that all monks and nuns should run their lives, monasteries and hospitals according to the Benedictine Rule. Montecassino was sacked by the Lombards in the $6^{\text {th }}$ century, rebuilt in the next century and again sacked (by the Saracens) in 884 . In the $10^{\text {th }}$ century it was finally reconstructed (Aitken 1984:11; Major 1954:272).

Other famous monastic hospitals built at this time included those at Merida, Spain (580), St. John's Hospital at Ephesus (610), Pantokrator in Constantinople ( $7^{\text {th }}$ century), Hôtel Dieu at Paris (651), Montpellier (738), St. Albans in Engeland (794), St. Maria della Scala, Siena (898), and St. Bernard's Hospital in the Swiss Alps (962) (Aitken 1984:12).

Concomitant with these developments, the Islamic conquests of the $7^{\text {th }}$ and $8^{\text {th }}$ centuries had given rise to the Golden Age of Islam ( $9^{\text {th }}$ to $13^{\text {th }}$ centuries) which facilitated a unique contribution to medical development and hospitalisation. This will be dealt with later.

3 Benedict's original Rule called for the establishment of an infirmary in every monastery and placed the care of the sick "above and before every other duty" (Green 1985:200, 240). 


\subsection{Late Middle Ages (beyond the $10^{\text {th }}$ century)}

Gradually the driving force behind hospitalisation in Europe changed from almost exclusively monastery-associated to greater participation by civil authorities. The monastic infirmaries continued to expand, but in large centres the city fathers initiated hospitals driven by civil support, whilst church authorities also opened public hospitals. And in addition specialised institutions like leper hospitals made their appearance (Aitken 1984:12, 13; Porter 1997:122).

Monastic institutions gradually expanded their medical services, previously restricted to infirmaries, to the community. Famous new hospitals appeared, like St. Bartholomew's (1137), St. Mary's (1179) and St. Thomas (1215) in London, the Holy Cross hospital in Winchester (1132) and St. John's in Canterbury (1118). During the $12^{\text {th }}$ century a monastic order was founded by Pope Innocent III, which led to the establishment of a Hospital of the Holy Ghost in most major cities. It was said that Islamic hospital design greatly influenced the construction of the first of these hospitals, the Santa Spiritus in Rome (1198). The Holy Ghost hospital built at Montpellier (1145) became one of Europe's first great teaching hospitals (Aitken 1984:13-14; Allan 1990:456; Mundy 1998:86-87).

The public hospital movement in large cities was financed by city authorities as well as the Church and even private sources. Lay physicians played an increasingly important role, especially after the Church placed a ban on monks practising outside monasteries. The medical dogma, here and in monastic institutions, was based mainly on the teachings of Galen and Hippocrates, which was also greatly admired by contemporary Islamic physicians (Allan 1990:451).

In Islamic Jerusalem the Order of the Hospital of St. John was founded by Brother Gerhard in the $13^{\text {th }}$ century as a charitable organisation caring for sick pilgrims in the Holy Land. A warrior element developing from the order, took part in the Crusades, and when Acre fell (1291), the movement was allowed to depart to Cyprus. From here it moved to Rhodos (1309), then settled in Malta (1530) and eventually moved to Rome. They became known as the Hospitallers in view of their intrepid and selfless record of charitable endeavours and hospital building in particular. The best known of these were at Mont- 
pellier, Rhodos, Prussia and at various sites in Italy. The present day St. John's Ambulance evolved from the Hospitallers. The related Templars (Order of the Poor Knights of Christ and Temple of Solomon, or the Teutonic Knights) remained involved in religious-military matters rather than charity, and amassed great power and wealth but were suppressed by Pope Clement V in 1312 (Major 1954:267; Mundy 1998: 86; Chrystal 2000:536, 1079).

Generally speaking, public hospitals (above) did not specialise, but in time certain specialised institutions did arise. Although the Basilica in Caesarea ( $4^{\text {th }}$ century) already had quarters for lepers, it is probable that leper houses (Lazar Houses; lazarettes; leprosaria) really originated during the $11^{\text {th }}$ century when Europe started experiencing an epidemic of leprosy. When this abated in the $15^{\text {th }}$ century, the leper houses were transformed by civic authorities into mainly mental asylums or infectious diseases hospitals. During the $13^{\text {th }}$ century there were 19000 leper houses in Europe, mostly run on a self-governing basis. During the early $14^{\text {th }}$ century a maternity hospital was built at Metz. There were also homes and hospitals for the aged, which partly evolved out of the monastic infirmaries, but were later run as independent charity institutions. Relatively small and often housing the apostolic number of 13 inmates, these homes were widespread and many large hospitals, like Strasbourg's St. Leonhardt's and Nurnberg's Holy Ghost Hospital, had sections for the elderly. Larger Jewish communities e.g. in Cologne and Regensburg had their own hospitals (Mundy 1998:86-87).

\section{ISLAM}

With their eastern conquests consolidated and the western offensive decisively defeated at Tours by a Frankish army under Charles Martel (723), the Islamic revolution, started by Muhammed in 632, consolidated its gains and moved into a period of remarkable stability and development - the Golden Age of Islam, which terminated in the $13^{\text {th }}$ century. Whereas Europe was experiencing an era of socio-scientific stagnation, eventually ended by the Renaissance, Islam succeeded in stimulating development and original thought. In spite of medical science in Europe stagnating around the doctrines of Galen, hospitalisation did expand (as described above). In Islamic countries foreign students were welcomed, and Greek medical dogma was greatly admired, 
studied and translated into Arabic. ${ }^{4}$ Physicians like Rhazes (866-932), Albucasis (936-1013), Avicenna (980-1037), Avenzoar (1091-1162), Averroes (1126-1198) and Maimonides (1135-1204) made important contributions, and in the field of hospitalisation great strides were taken (Major 1954:225-258).

Taking their example from the Christian (Nestorian) teaching hospital at Jundi-Shapur, Islam developed its own impressive hospitals (bimaristans) at Cordoba, Baghdad, Damascus, Bokhara, Sevilla and Cairo. A total of 34 major ones have been identified. Tudela, who visited Baghdad in 1160, wrote that there were 60 hospitals in that city and 50 in Cordoba. The greatest and most magnificent was the Mansuri hospital in Cairo (completed in 1284). This self-contained institution had four great courts, each with a water fountain in the centre, separate wards for men and women and for different diseases, a dispensary, lecture halls, and an out-patient department (from where patients were visited at their homes), a chapel and library. Fever wards were cooled by fountains. Musicians and storytellers entertained the sick, and on discharge each patient received a sum of money sufficient to pay for immediate expenses until he could resume work (Major 1954:260; Porter 1997:104-105; Guthrie 1958:95, 96).

Possibly the first mental hospital for the insane (a maristan) in Europe was built by Islam in Granada in 1365 (Porter 1997:105).

The hospitals at Cordoba, Baghdad, Damascus and Cairo in particular, also served as centres of medical education, attracting students from Europe and the Far East, spanning the void of Medieval scientific stagnation until the creation of Europe's own fledgling medical schools at Salerno $\left(11^{\text {th }}\right.$ century), followed by Montpellier and Bologna $\left(13^{\text {th }}\right.$ century), Padua and Paris (14 ${ }^{\text {th }}$ century) (Guthrie 1958:95-96, 102-124).

\section{HOSPITALS AND MEDICAL EDUCATION}

After the Renaissance when medical schools in cities like Padua, Bologna and Montpellier initiated the blossoming of medical knowledge after Medieval stagnation, centres of medical excellence were almost

4 In Medieval times Arabic became the lingua franca of science (Major 1954: 223-225). 
invariably associated with great teaching hospitals. This was indeed a new development. Although the Renaissance cities mentioned above did have hospitals, the primary initiative leading to scientific development originated in their universities rather than their hospitals. With few exceptions, e.g. in the field of surgery (Ambroise Paré, Guy de Chauliac) and women's diseases, the advances were not in clinical medicine, but in anatomy (e.g. Vesalius), physiology, herbalism and philosophical fields of study. Hospitals and clinical medicine became an essential component of the doctors' training only when physicians like Sydenham $\left(17^{\text {th }}\right.$ century) and Boerhaave ( $18^{\text {th }}$ century) made the patient pivotal in medical education (Guthrie 1958:202-204, 220-224).

Hippocrates $\left(5^{\text {th }}\right.$ century BC) did of course emphasise the importance of clinical contact and expertise in medical practice, but neither he nor Galen nor any other Greek physician of status had access to teaching hospitals (which did not exist at the time). In the Roman era with the advent of hospitals (valetudinaria initially) we have little evidence that these played a significant role in the furthering of medical science. Harig (1971:188) makes the point that eminent doctors of the quality of Galen were apparently never associated with valetudinaria, although he did treat gladiators early in his career. The famous Alexandrian school of medicine (founded c.300 BC) where human dissection was performed for the first time, was well known for its magnificent library and museum, but not for a hospital of significance.

In the Christian era the Church progressively monopolised the predominantly monastic hospital system, which for its time rendered an able service to the ill and the aged, but contributed little to the advancement of medical science (Harig 1971:97). In fact, it is fair to say that through its strict and slavish adherence to the dogma of Greek masters like Galen, the Church repressed original thought, and left it to the doctors and hospitals of Islam to carry the flame of medical knowledge through the dark Middle Ages to the new dawn of the Renaissance (Retief \& Cilliers 2001: pp. 259-277 in this volume). The major Islamic hospitals served as centres of medical education, and in that sense they were the true forerunners of the modern medical teaching hospital. 
REFERENCES

\section{Aelius Aristides}

1981. Complete works (transl. C.A. Behr). Leiden: E. J. Brill.

\section{Aitken J T, Fuller H W C \& Johnson D}

1984. The influence of Christians in medicine. Nottingham: Intervarsity.

\section{Allan N}

1990. Hospice to hospital in the Near East: an instance of continuity and change in late antiquity. Bull. Hist. Med. 64:447-450.

\section{CATO AND VARRO}

1934. On agriculture (transl. W.D. Hooper \& H.B. Ash). London: W. Heinemann. Loeb Classical Library.

\section{Celsus}

1948. On medicine (transl. W.G. Spencer). London: W. Heinemann. Loeb Classical Library Vol. 1.

\section{CHRYSTAL D (ED.)}

2000. The Cambridge encyclopedia. $4^{\text {th }}$ Edition. Cambridge: University Press.

\section{Cilliers L}

1993. Public health in Roman legislation. Acta Classica 36:1-10.

\section{COLUMELla}

1955. On agriculture (transl. E.S. Forster \& E H Heffner). London: W. Heinemann. Loeb Classical Library Vol. III.

Corpus Iuris Civilis. Codex IUstinianus

1888-1904. Recognovit P. Krüger. Berlin: Weidman.

\section{CYPRIAN}

1979. De mortalitate. In: E S Forster (ed.), Cyprian. Orations. New York: Arno Press.

\section{DigeSTA}

1818-1825. Pandectae Justinianae, in novum ordinem Digestae: cum legibus Codicis, et Novellis, quae jus Pandectarum confirmant, explicant aut abrogant. Auctore R.J. Pothier. Paris: Fournier.

\section{EUSEBIUS}

1932. Ecclesiastical history (transl. J.E.L. Oulton). London: W. Heinemann. Loeb Classical Library Vol. II.

\section{Ferngren G B \& Amundsen D W}

1996. Medicine and Christianity in the Roman Empire. In: Aufstieg und Niedergang der römischen Welt II.37.3. Berlin: W. de Gruyter, pp. 2957-2980. 
The evolution of hospitals

\section{GREEN M H}

1985. The transmission of ancient theories of female physiology and disease through the early Middle Ages. Ph. D. Princeton University.

\section{GREGORY OF NAZIANZUS}

1800-1875. Orations. In: J.-P. Migne, Patrologiae Graecae. Vol. xxxvi. Turnhout Brepols Leuven: University Press.

\section{GUTHRIE D}

1958. A bistory of medicine. Edinburgh: Nelson \& Sons.

\section{HAEGER K}

1988. The illustrated bistory of medicine. London: Harold Starke.

\section{HARIG G}

1971. Zum Problem "Krankenhaus" in der Antike. Klio 53:179-195.

\section{HORNBlOWER S \& SPAWFORTH A (EDS.)}

1996. The Oxford Classical Dictionary. $3^{\text {rd }}$ Edition. Oxford: University Press.

\section{JACKSON R}

1988. Doctors and diseases in the Roman Empire. London: University of Oklahoma Press.

\section{JULIAN}

1923. Letters. Epigrams. Against the Galileans. Fragments (transl. W.C. Wright). London: W. Heinemann. Loeb Classical Library.

\section{LEWIS C T \& SHORT C}

1958. A Latin dictionary. Oxford: Clarendon Press.

\section{LIVY}

1926. History of Rome (transl. E.T. Sage). London: W. Heinemann. Loeb Classical Library.

MAJNO G

1975. The healing hand. Man and wound in the ancient world. Cambridge MA: Harvard University Press.

\section{MAJOR R H}

1954. A bistory of medicine. Springfield Ill.: Charles C. Thomas.

\section{Mundy J H}

1998. The High Middle Ages. London: Longman Group UK Ltd.

\section{Ovid}

1914. Metamorphoses (transl. F J Miller). London: W. Heinemann. Loeb Classical Library.

\section{Philips E \& Allan T (EDS.)}

1993. The divine campaigns AD 1100-1200. Amsterdam: Time Life Books. 


\section{PORTER R}

1997. The greatest benefit to mankind. London: Harper Collins.

\section{REINER E}

1964. Medicine in ancient Mesopotamia. Journal of the International College of Surgeons 41(5):544-549.

\section{Retief F P \& Cilliers L}

2001. The influence of Christianity on Graeco-Roman medicine up to the Renaissance. Akroterion 46:61-73. [pp. 259-277 in this volume.]

\section{SCHEIDER K}

1953. Valetudinarium. Paulys Realencyclopaedie der classischen Altertumswissenschaft. Band VIII.A.1. Leipzig: Mettlersche Buchgesellschaft, pp. 262-6.

\section{SCriptores Historiae Augustae}

1921. Severus Alexander (transl. D. Magie). London: W. Heinemann. Loeb Classical Library Vol. II.

\section{SENECA}

1926. De ira (transl. J.W. Basore). London: W. Heinemann. Loeb Classical Library Vol. 1.

\section{ST. JEROME}

1933. Select letters (transl. F.A. Wright). London: W. Heinemann. Loeb Classical Library.

\section{STACCIOLI E E R}

1988. Ancient Rome. Monuments past and present. Rome: La Zincografica Fiorentina.

\section{SUETONIUS}

1996. The lives of the Caesars. Claudius (transl. J.C. Rolfe). London: W. Heinemann. Loeb Classical Library Vol II.

\section{TACITUS}

1937. Annales (transl. J. Jackson). London: W. Heinemann. Loeb Classical Library Vol. IV.

\section{ThOMPSON J D \& GOLDEN G}

1975. The hospital: a social and architectural study. New Haven \& London: Yale University Press.

\section{VALERIUS MAXIMUS}

2000. Memorable doings and sayings (transl. D.R. Shackleton Bailey). London: W. Heinemann. Loeb Classical Library.

\section{VITRUVIUS}

1931. On architecture (transl. F. Granger). London: W. Heinemann. Loeb Classical Library. 
The evolution of hospitals

\section{WALLACH L}

1951. Alcuin. De litteris colendis. Letter 56 to Eanbaldum. Speculum 26.

\section{WOODHEAD A G}

1952. The state health service in ancient Greece. The Cambridge Historical Journal 10(30):235-253. 